\title{
A remarkable story! M.C. Vos (1759-1825) in the light of his times
}

\author{
Author: \\ Benno Zuiddam ${ }^{1}$ \\ Affiliation: \\ ${ }^{1}$ Theological Faculty, \\ School for Biblical Studies \\ and Ancient Languages, \\ North-West University, \\ South Africa \\ Correspondence to: \\ Benno Zuiddam \\ Email: \\ benno.zuiddam@nwu.ac.za \\ Postal address: \\ 110 Panorama Road \\ Blackstone Heights, \\ Tasmania 7250, Australia \\ Dates: \\ Received: 01 Sept. 2010 \\ Accepted: 24 Feb. 2011 \\ Published: 23 Nov. 2012 \\ How to cite this article: \\ Zuiddam, B.A., 2012, 'A \\ remarkable story! M.C. Vos \\ (1759-1825) in the light of \\ his times', In die Skriflig/In \\ Luce Verbi 46(2), Art. \#56, \\ 12 pages. http://dx.doi.org/ \\ 10.4102/ids.v46i2.56
}

(C) 2012. The Authors.

Licensee: AOSIS

OpenJournals. This work

is licensed under the

Creative Commons

Attribution License.
This article established the role of the Rev. M.C. Vos (1759-1825) as an internationally oriented Pietistic minister who encouraged mission work amongst the slaves and non-Europeans in the Cape Colony. It clears up several misunderstandings about Vos's genealogy and argues that there is no genealogical warrant to treat Vos as something else than a White, European minister and writer. His cultural setting and ancestry was that of a colonial Dutchman, although it may have been Euro-Asian to some small extent. If so, this could have predisposed him naturally to look kindly on the lot of Bengal and Malayan slaves. The real motivating factor for Vos's missionary endeavours was not racial, but spiritual. The promotion of the Gospel and knowledge of the Scriptures was foremost in the mind of this Dutch Reformed minister. This article argues that the Bible and divine guidance had a remarkable influence on the life and actions of M.C. Vos, to the extent that even his autobiography is marked by Biblical language. Vos is placed within the historical perspective of his times, which assists a balanced interpretation of this remarkable person and his convictions.

'n Merkwaardige verhaal! Die lewe en historiese omstandighede van M.C.Vos (1759-1825). Hierdie artikel het die historiese rol van Ds. M.C. Vos (1759-1825) vasgestel as 'n internasionale Piëtistiese wat sending bedryf het onder die slawe en nie-Europeërs aan die Kaap. Dit helder misverstande op wat ontstaan het oor die genealogie van Vos en stel dat daar geen genealogiese rede is om Vos te beskou as 'n predikant en skrywer van nie-Europese afkoms nie. Sy kultuur en voorgeslag was dié van 'n Nederlandse kolonis, hoewel daar enige Euro-Asiatiese elemente in sy genealogie mag wees. Indien dit die geval is, dan het dit bygedra tot sy natuurlike simpatie vir die lot van die Bengaalse en Maleise slawe. Hierdie artikel toon egter aan dat die motivering vir die sendingarbeid van Vos nie op rassistiese gronde berus het nie, maar op die Woord van God. Die verkondiging van die Evangelie en die bevordering van die kennis van die Skrif was die beweegrede van die Nederduits Gereformeerde predikant. Hierdie artikel toon aan dat die Bybel en buitengewone Goddelike leiding 'n merkwaardige invloed uitgeoefen het op die lewe en dade van M.C. Vos, selfs sodanig dat sy lewensbeskrywing deurspek is met Bybelse taalgebruik. Vos word in historiese perspektief geplaas om sy merkwaardige persoon te verstaan in die lig van sy tyd en oortuigings.

\section{Introduction}

\section{Problem statement}

In historical research there is always the temptation to make the object of one's research as relevant to one's own time as possible. This has happened to the subject of this article, the Rev. Michiel Christiaan Vos. He is known as South Africa's first mission-man, but is this in fact the case? Is it possible that a convincing case for earlier candidates can be put forward? We live in postapartheid days that invite possibility thinking. Looking at his genealogy, was Vos perhaps a Black person of mixed race himself? Did he therefore feel a natural desire to minister to his own people who were less fortunate? This article will explore this issue. What was the real motivation in the life of Vos if one takes the primary source of our information, his autobiography, into account? This article is built around the central theory that, in his missionary endeavours, Vos was driven by his understanding of the Bible and a spiritual calling he felt in this regard. Although Vos's convictions and activities are not surprising in the light of the times and his family history, his life story remains remarkable for its commitment, achievements and actual events. If not anything else, it is riveting as a travelling account of a man on a mission under divine guidance.

\section{M.C. Vos \\ Brief overview}

The Rev. Michiel Christiaan Vos was a Dutch Reformed minister, born at the Cape of Good Hope. He was internationally oriented. Within the wider setting of the Dutch East India 
Company (VOC) Vos worked and served on the continents of Europe, Africa and Asia. With others, like the Rev. Andrew Murray, he is remembered as one of the wellknown sons of the Cape, who left their mark on the history of the Dutch Reformed Church and South Africa in general (cf. Conradie 1951:136-137). Like the Murrays and the Neethlings, Vos would also have a genealogical effect on the Church, not only through his teaching, example and autobiography, but through his children as well.

Michiel Vos was converted or spiritually awakened in the circles of the so called conventicles, that is, small house church groups where Christians shared their spiritual walk and experience. His older brother, with whom he did his apprenticeship for silversmith, encouraged this as well. Generally speaking, Puritan and Calvinistic values prevailed in these circles, often combined with what outsiders might refer to as mysticism, or at least a more emotional approach to their faith. Like his family before and after him, Vos was committed to the cause of Pietism. Together with the Rev. H.R. van Lier (cf. Hanekom 1959:313-314), he was instrumental in changing the somewhat rationalistic approach to preaching and ministry in general, claiming a rightful place for emotions and the intimate, personal side to faith.

\section{Biographical overview}

Even for those familiar with Vos's autobiography, Merkwaardig Verhaal, it is helpful to have a general overview of the facts of his life:

1759 - Born in family characterised by Pietism (Nadere Reformatie' [Second Reformation]).

1765 - Father dies.

1776 - Receives spiritual illumination after conversion-process that took several years. Desires to become a minister and to evangelise the slaves and Hottentots. ${ }^{1}$

1779 - Marries Elizabeth Jacobs to become legally of age so as to gain access to inheritance from his father to study theology in the Netherlands. Arrangement with in-laws that wife will remain in the Cape Colony.

1780 - Leaves for Holland, whilst frivolous French troops are stationed at the Cape.

1781 - After preliminary classical studies, he enters theological academy in Utrecht and moves in conservative reformed, Voetian, circles.

1784 - Graduates and serves as curate in Amsterdam.

1785 - Becomes minister in Woudenberg, as he was passed by for appointment at the Cape for political reasons.

1789 - Becomes minister in Pijnacker.

1790 - Becomes minister in Woerden.

1793 - Appointment in Roodezand (since its separation from Stellenbosch in 1804 known as Tulbagh), Cape Colony.

1794 - Induction in the parish of Roodezand.

1797 - First travels to the Eastern border; writes to Holland about the pressing need for missionaries. This request

1.The term Hottentots reflects the historical sources and is used without racial prejudice. is passed on from the Dutch Missionary Society to England.

1799 - Arrival of four missionaries from the London Missionary Society, Van der Kemp amongst them. First missionary organisation, Het Zuid-Afrikaansche Genootschap ter bevordering van de Uitbreiding van Christus Koninkrijk is formed. Vos is one of eight directors.

1800 - Defamation of character; cleared from accusations of improper sexual relationship with servant; officially retracted by initiator before the judge of the district.

1802 - Leaves for England after official farewell to Roodezand, with notice to the government as the employer of ministers of the established church.

1803 - Sent out to Ceylon (Sri Lanka, formerly Dutch, later English).

1804 - Wife dies in Tranquebar (southern India); appointed minister of the Dutch Reformed Congregation in Point de Gale (south-western Ceylon/Sri Lanka); remarries officer's widow, Johanna van Geysel, who was born in the Indies; struggles to combat ignorance about the doctrines of Christianity amongst the scores of people who adhere to the godsdienst der Compagnie [the religion of the Dutch East India Company]; confronts local ministers on low moral standing.

1809 - Returns to Cape Town, where the English have taken over; receives appointment from government in Zwartland (Malmesbury); even before his arrival there is 'dissatisfaction of the community at large', because of Vos's enlightened ideas about the promotion of the Gospel amongst slaves and Hottentots.

1810 - Induction to new post; in charge of Zwartland, but initial poor attendance as farmers regret his arrival.

1811 -Minister in Zwartberg (since 1813 changed into Caledon, by Gov. J. Cradock).

1812 - Annulment of the 1770 law that prohibited the sale of Christian slaves; Vos had argued for this as farmers feared material loss should their slaves convert to Christianity.

1818 - Retires to Tulbagh (formerly Roodezand) because of ill health.

1819 - Writes his autobiography in the format of letters to a friend:

Merkwaardig verhaal aangaande het leven en de lotgevallen van Michiel Christiaan Vos, als predikant der hervormde christelijke gemeente op onderscheidene plaatsen in Nederland, Afrika en Azië, van zijne Jeugd af tot den tijd van zijn Emeritusschap door hem zelven in den Jare 1819 briefsgewijze aan eenen vriend medegedeeld [Remarkable story of the life and times of Michiel Christiaan Vos, as minister of the Reformed Christian Church in several places in Netherland, Africa and Asia, from his Youth until the time of his Retirement, communicated by himself in the Year 1819 as letters to a friend.] (Vos 1824, [author's own translation])

1824 - First edition Merkwaardig verhaal published by A.B. Saakes in Amsterdam.

1825 - Vos dies in Tulbagh (without seeing his published autobiography). 


\section{Misunderstandings Mission work before the 19th century societies}

A common misconception is that Dutch Christianity in South Africa never considered the spiritual needs of non-Europeans until Vos and others arrived on the scene. Huigen (1997:205) is an exponent of this view and singles out the issue when he states, 'De Gereformeerde Kerk had gedurende de hele VOC tijd geen aandacht voor zendingwerk gehad.' [The Dutch Reformed Church had never paid any attention to mission-work in the time of the VOC.] This is not entirely true, to use an understatement. In order to understand the Cape and Vos's life in their proper historical context, it would be helpful to clear up this rather common misconception.

Generally, the Company encouraged the spread of Christian teaching through the established Dutch Reformed Church. In Ceylon, for instance, this was so successful that in 1723 the Dutch Reformed Church counted well over 200000 members (Algra \& Algra 1972:130). By the time of M.C. Vos the printed statistics revealed that there were 342000 Protestant Christians (Vos 1824:145). Although Vos judges the quality of Christianity at Ceylon at that time very negatively, the fact that there were only nine ministers for such a vast number of people, most of them not very committed at all, must have had something to do with the poor state of affairs. The large membership of native Dutch Reformed Christians at Ceylon in VOC (Dutch East India Company) days, however, shows at the very least that an effort had been made.

The settlement at the Cape was specifically founded with the goal of creating Christian missions as well as commerce. The VOC started the Cape Colony with the explicit hope that this would lead to the spread of Christianity amongst the natives. This is reflected by the meeting of its directors. The Heeren XVII (The Lords XVII, the board of directors of the VOC) desired that Christianity should be furthered amongst the gentiles from the very start of the Cape Colony.

When Johan van Riebeeck set sail on 24 December 1651 he carried with him a prayer from the Heeren XVII which they wished to be read. It explicitly petitioned from the Almighty '... onder deze wilde brutale menschen mogelijck sijnde Uwe ware gereformeerde Christelijke Leere metter tijdt mochte voortgeplant ende verbreijt worden, tot uwes $H$. Naems lof ende Eere'. [... that amongst these wild and brutal people it be possible that thy true reformed Christian Doctrine would find root and spread, to the praise and glory of thy holy Name]. (Full prayer included in Algra IV 1972:119).

This was an important issue for Van Riebeeck and he reported back to the Lords XVII:

Wel ende in goede correspondentie met haer levende, sal men metter tijd eenige van haer kinderen tot jongens ende dienaers gebruijcken ende in Christelijcke religie optrecken waer door als Godt almachtigh dese goede saecke gelieffden te segenen, gelijck Al Taijouan ende Formosa, heeft gedaen, veel zielen tot de Christelijcke gereformeerde religie ende Godt toegebracht warden. Sulcx dat het maken van voornoemde fort ende thuijn, niet alleen sal strecken tot voordeel ende proffijt van d' Ed. Com. maer tot preservatie ende behoudenisse van veel menschen leven, dat het treffelijckste is tot grootmakinge van Godes alder heijligste Name, voortplantinge sijner h. Evangeli, waerdoor buijten twijffel UEd. Handelinge in geheel India meer en meer sal gesegent worden. [And maintaining good contact with the natives, one should be able to, in time, use their children as helpers and servants and draw them up into the Christian religion, if God Almighty be prepared to bless this good cause, just as it happened in Al Taijouan and on Formosa, where many souls were added to the Christian reformed religion and brought unto God. Seen in this perspective, the building of the fort and garden we spoke about, shall not only serve the advantage and profit of the esteemed Company, but also preserve and save much human life, which contributes most to the praise of God's most holy Name, the spread of his holy Gospel, because of which without doubt your esteemed enterprises in the whole of Asia shall be blessed more and more.] (Algra \& Algra 1972:123, [author's own translation])

From the correspondence of the lay Chaplain Wijlant to the Classis Amsterdam, it is also clear that the early Dutch leadership at the Cape made serious attempts to reach the Khoi, or Hottentots as they were known at the time with the Gospel, but that this was a hard call. The history of Eva, who was adopted by the Van Riebeeck household and married a European is indicative. The Khoi were not interested in the Dutch in general (cf. Marks 1972:55-80). Subsequently, their Christian endeavours were concentrated on the slave population instead.

When the Dutch plans to integrate the Khoi and use them as part of the workforce in the new colony failed, the Company imported slaves from Bengal (greater India) instead. Many domestic workers and farmhands came from Bengal and also the Coromandel Coast and Kerala, usually through Batavia, the main sea of the VOC, where many ended up. The archives from the early days show that several marriages took place with Bengali women who were set free. During 1656 two such marriages were permitted (Jan Wouters with Catherine of Bengal, and Anton Muller who married a woman from Bengal as well). The slave population (roughly 200 in 1685) received instruction in the Christian religion.

Consequently, one could state that there has always been an interest in mission work during the days of the VOC, but that this was attempted through established relationships. Mission work was not a special enterprise, but was part of the spread of Dutch culture at the Cape. As the Dutch entered into relationships, their contacts were also instructed in the true Christian reformed religion. It came with a cultural package, but then, all mission work does and this, at least, was an integrated package. The work of the Societies in the 19th century often aligned with the cause of the British Empire and several other political causes advanced by the English Liberal Party at the time. This was, for instance, reflected in attitudes to slavery and polygamy, whilest British commerce and empire-building were promoted hand-in-hand with many evangelical missions. This was most prominently embodied in David Livingstone. 


\section{Genealogy of the Vos family}

M.C. Vos's family tree has been subject to misunderstandings, both in popular literature and in serious journals in South Africa, as well as in Holland. Richard Elphick (1997:274) disparages Vos's genealogy as that of 'a mulatto slave owner'. More recently the Reformatorisch Dagblad (Reformed Daily, 28 April 2010: Opwekking liet sporen na in Woudenberg) reported on a lecture by Dr W. van Vlastuin (revival scholar and lecturer at the seminary of the Hersteld Hervormde Kerk at the Free University in Amsterdam) on the revival in Woudenberg during Vos's ministry. Van Vlastuin undertook what he describes as 'investigative research' (speurwerk) on the genealogy of the Rev. M.C. Vos, leading to the conclusion that he was born in South Africa as the son of a White father and a coloured mother, probably a female slave who was set free. There has been some speculation about his maternal grandmother in this regard, which was fed by Prof. Huigen's article on the subject in the Tydskrif vir Nederlands en Afrikaans in 1997. This theory was revived more recently by Van Rinsum's book (2006:27) on the ties between Stellenbosch and Utrecht University. This interpretation is based on an excusable but wrong reading of the Vos genealogy.

In this context it was also proposed that Vos was 'South Africa's first Black writer'. To appreciate the historical context of the times from a modern perspective, it is helpful to realise that during Vos's time South Africa did not exist. Geographically there existed Southern Africa and the Cape Colony (a very small portion of present day South Africa). Vos (1824:107) himself calls it De Kaap almost without exception, and sometimes 'Afrika' (e.g. Vos 1824:87) in contrast with Europe and Asia. South Africa as a national entity only came into being 85 years after Vos passed away (Union of 1910), after the fall of the Zuidafrikaansche Republiek (Transvaal) to the British in 1901.

Huigen (1997) not only suggested that Vos should be called 'de eerste zwarte schrijuer in Zuid-Afrika' [the first Black writer in South Africa], he also says:

Bovendien is het eerste boek van een zwarte schrijver uit ZuidAfrika. Bij dat laatste moet ik wel aantekenen dat dit gegeven opmerkelijker is voor onze tijd dan voor de tijdgenoten van Vos. [What is more, this is the first book by a Black writer from South Africa. Although I should say that this is more remarkable in our time than for the contemporaries of Vos.] (p. 203, [author's own translation])

'Black' in the context of Huigen's article should be understood as 'non-European'. Huigen connects this with (what he considers to be) Vos's maternal grandmother: 'Zijn grootmoeder van moederskant was Anna Groothenning van Bengalen'. Huigen (1997:205) argues: '[o]p grond van het toponiem mogen we aannemen dat zij een (vrijgelaten) slavin was, want emigratie naar de Kaap vanuit Bengalen was doorgaands gedwongen in de VOCtijd.' [On the basis of the geographic allusion we may assume that she was a (released) slave, as emigration to the Cape from Bengal in VOC days was usually forced.]

Considering that Black in the context of a South African academic journal is probably an ambiguous way to describe Bengal's natives, who are Indians, for practical purposes this article shall test the claims for Vos's alleged 'non-European' descent'. It intends to show that the genealogical data rules out the possibility that Vos's mother was a slave. Several considerations apply.

Firstly, even if his maternal grandmother was a slave from India, this remains a supposition, as firm proof for this background is lacking. The geographic allusion may be argued either way. Dutchmen still like to call fellow countrymen 'emigrants' by their country of settlement. This has no bearing on their bloodline at all. Anna may have been born to Dutch migrants, East India Company people for all that we know, two or three centuries later. She may have been a convict exiled to the Cape.

Secondly, even if the reference to Bengal indicates a former slave, which should at least be contemplated, all that it does is add a little Asian blood onto the mother's side, whilst the European family tree for the Vos family as such is left intact. Anna's husband (Christiaan Bok, Michiel's maternal great-grandfather) was a German, making the bloodline European. Even if Anna was Vos's great-grandmother, the main bloodlines are of White people, despite some Asian influence. Vos was not a non-European writer, but a White European in culture and main descent.

Thirdly, the major problem has an even more significant genealogical nature. It is doubtful whether Anna of Bengal ever was Vos's great-grandmother in the first place. She probably never was part of his family line at all. There is every reason to believe that Vos's maternal grandmother was not Anna of Bengal, but a Dutch lady called Elisabeth van der Poel, whose parents were both born in Holland. Anna could not have been Vos's grandmother, as she was married to his great-grandfather, not his grandfather. This makes the alleged Asian element in the bloodline on the mother's side almost negligible. Although it was true that Christiaan Bok was Vos's great-grandfather, his marriage with Anna was a second marriage. Vos's grandmother was born from an earlier wife who passed away and whose particulars have been lost in the mists of time. Their son Michiel Bok (born 1702) was M.C. Vos's maternal grandfather (according to genealogical research by the family) (cf. Rosseau 2002). On his father's side, Vos's ancestry is German. His grandfather J.H. Vos was German, and the name of his wife Christina Baumann, should be self-explanatory, although she may have had Asian blood. Their son Jan Hendrik was born in Batavia and married Michiel Bok and Johanna van der Poel's daughter, Johanna, at the Cape.

Consequently, Jan Hendrik's wife was not the daughter of a slave, like some supposed (e.g. Huigen 1997:204), but the very Dutch, Elisabeth van der Poel. The Rev. Michiel Christiaan Vos was their fifth child. The family tree is somewhat complicated as Johanna's four children (Johannes Hendrik, Hendrik, Jacobus Johannes and Michiel Christiaan Vos) are listed amongst the heirs of their aunt, Anna Bok, in some of the documentation. 
Traces of Vos's German ancestry may be found in his autobiography as well. As a youngster he used to sing at home from the Dutch Psaltery, but also the German Hymnary (Vos 1824:6). After his first wife passed away, Vos remarried Johanna van Geyzel at the age of 46 with whom he had eight children. Five were still alive when he wrote his autobiography in 1819. According to the family, he used to refer to his second wife as 'mijn Oostersche prinses' [my eastern princess] (Rosseau 2002). In his autobiography Vos refers to her as 'mijne lieve Aziatische echtgenoote' [my dear Asian wife] (Vos 1824:194). This was not because she was an Asian by race at all, but because that is where he met her and where she had lived. Vos (1824) himself makes this clear in his book, indicating the degree of relief she brought to his life: 'van Hollandse ouders, die waarlijk van mijnen God bestemd was om mijne tranen af te drogen'. [who was from Dutch parents, and was truly ordained by God to wipe off my tears]. (p. 166).

Vos refers to his first wife in a similar geographical way as his African wife. From his autobiography there is every indication that his first wife was chronically depressed for most of their married life. She was sickly and grumpy as a result (Vos 1824:135) and only reluctantly moved to the Netherlands when Vos initially did not receive an opportunity at the Cape. This was all very understandable in the light of the personal sacrifices that she had made to support her husband's ministry. She was married to an absent husband for four years during the prime of her life to facilitate his studies. Her patient expectation of his return was rewarded by being taken away from her family to the other side of the world. When she and her husband finally returned to the southern tip of Africa after 14 years overseas she was an emotional wreck and wanted to return to Holland. Their marriage remained childless and rumours about an adulterous relationship with their maid in Roodezand would have put added pressure on their union. There must have been a certain degree of material hardship as well. For example, when they made it to England they lost most of their worldly possessions to the London customs. This was the remnant of their money after a forced expensive stay on St Helena. Vos's wife was ill-suited to non-European servants (Vos 1824:127) and must have had her misgivings when the London Missionary Society pressured her enthusiastic husband to go to Ceylon and leave his wife behind in Europe, albeit in the care of the London Missionary Society (LMS) (Vos 1824:144). The fact that despite his initial firm objections he was prepared to go to Ceylon once he knew his wife would be taken care of is probably indicative of the nature of their relationship and her vulnerable mental state. In the end Vos's wife recovered sufficiently to go with him to Ceylon, but died along the way. Vos (1824) says about her:

$\mathrm{Nu}$ is zij intusschen alles te boven, en al sedert lang, zo ik vertrouw, om de verdiensten van Jezus, uit genade, van het een en ander geheel verlost en volmaakt zalig. [Now, she is beyond all this, and for a long time already, as I trust, because of Jesus' merit, by grace, delivered from all of this and perfectly blessed.] (p. 135, [author's own translation])
In contrast, his second and much younger wife must have been a breath of fresh air. Not surprisingly, Oupa Michiel Vos referred to her in terms of endearment. The manner in which these two met was also special. The night before Vos set foot ashore, and before they had ever met, she had a dream about someone dressed in black who would take her ring from her finger. She shared the dream only a few weeks after their marriage:

Zij droomde juist in dien nacht, toen ik den volgenden morgen eerst aldaar aan wal en in den stad kwam, en zij volstrekt niets van mij wist: dat er iemand in het zwart gekleed tot haar kwam, en haren ring van haren vinger nam. Den daarop volgenden morgen in hare woning bij de glazen, welke op straat uitzagen, zittende, kwam haar droom haar juist in de gedacht, en terwijl zij hare oogen opsloeg, ging ik, juist uit de schuit komende, die straat door. Daar zij mij niet kende, verschrikte zij zeer, toen zij zag, dat ik dezelfde persoon was, die haar, in haren droom, den ring van haren vinger genomen had. [Whilst she sat in her house the next morning, looking out of the windows facing the street, she recalled this dream. And whilst she lifted her eyes, she saw me, after I had just left the ship, passing through the street. As she didn't know me, she was quite startled when she saw that I was the very person from the dream who had taken the ring from her finger.] (Vos 1824:166, [author's own translation])

In the light of the German elements in Vos's ancestry, it is interesting that as a Dutch Reformed minister he had natural sympathy for the Moravian Brethren and German missionaries in general. Some of his children and grandchildren intermarried with missionary families such as the Alheits and the Gerdeners. One of his daughters (M.J.S. Vos 1817-1906, Tulbagh) married the Rhenish missionary C.W. Alheit. One of her daughters married the Rhenish missionary, Johann Gerdener. Their son Gustav would become an influential professor at the Stellenbosch seminary, through whom the family continued to contribute extensively to the cause of missions in South Africa (cf. Gerdener 1951a).

\section{Pietism in Holland and the Cape Religion in the age of reason}

Theology in Holland, the motherland, felt the pressures of humanism, rationalism and deism. Even the sermons of the Puritans and reformed scholasticism suffered from a theoretical approach that resulted in endless divisions and subdivisions. Emphasis on the right theory rather than on revealed theology and experience called for the countermovements of Methodism, Pietism and also the Second Reformation, which as a particularly Dutch manifestation of Pietism stressed a reformation of life, but gradually suffered from overtones of predestination. In the United Kingdom this trend was found particularly in the movement of the Wesley brothers and Whitefield. Whilst in Holland, theology could be argued to contain a mixture of Reformed Pietism and the Second Reformation, the latter being rooted in the former movement (see W. van 't Spijker in Brienen 1986:5-12). All three movements emphasised the necessity of a personal relationship with God as an integrated part of life and encouraged a greater place for emotions in church life. To a lesser or greater degree they all suffered from a 
scholastic need to discern theoretically between different spiritual stages and to actively organise these emotions and stages through prescribed ways of preaching and the proper spiritual activities to counteract the flesh. Although in a completely different and thoroughly Protestant setting, some of it was not unlike Ignatius of Loyala's system of organised personal religion.

Although in spiritual opposition to the times, Pietism operated in the Age of Man leading up to the French and American Revolutions. In its own way Pietism was mancentred. It called man's personal spiritual state before God to the forefront, stressing outward or inward spiritual milestones, scholastically and philosophically discerning many steps on the road to the assurance of faith. Although this was a far cry from the autonomy of man in liberalism, it was perhaps not unlike the times. However, arguably, anything was better than empty rationalism with its Deistic and impersonal God as an absent architect of the universe.

\section{Spiritual concerns about the Cape}

The second half of the 18th century at the Cape of Good Hope saw a society that was marked by Christian charity. The diaconate took care of orphans and widows. Even those who had no money received an education and were instructed in the doctrines of the Christian faith in catechism class. The charity of the mother church in Cape Town, where Michiel Vos grew up, reached far beyond the borders of the Colony. The Church sent help to German congregations in Gulick and Wetzler and assisted travellers who passed through the Cape of Good Hope on their way to India or the mother country. The Church had become an established part of a society that was marked by a Christian culture. Although the government played an important if not central role even in the affairs of the Church, discouraging any regional form of church self-government, this also implied an official support for Christianity and its religious and moral values. By this time the Cape counted five congregations with duly educated and ordained ministers, but the consistory in Cape Town felt that she was the primus inter pares [first amongst equals], if not endowed with certain pope-like privileges as the reformed Rome of the South.

Despite all this, the Rev. M.C. Vos's experience of church life during his youth was not a happy one. He would have agreed with Ds. Serrurier's assessment of the spiritual state of the Cape Colony in 1765: '[v]eelvuldige lauwheid, zorgeloosheid en steunen op nietige rietstaven, hoewel de Heilige Geest nog niet geheel uit ons midden geweken is'. [A general lack of commitment, careless attitudes and ill-founded trust, although the Holy Ghost has not withdrawn from our midst completely.] (Morrees 1937:281-282).

Vos complained about the spiritual lifelessness and unprofitableness of visits to church in the days of his childhood. He protested against what he saw as a state of worldliness that was encouraged by travellers passing through from Europe and the East Indies. Since the FrenchEnglish war of 1756-1763, many more warships anchored at the Cape, usually with crews who did not excel in godliness. The Colony enjoyed the economic stimuli that those visits provided, especially during the years 1780-1784, when a French fleet was stationed at the Cape, whilst the Dutch Republic became involved in yet another war with the English, this time on the side of the French. Whilst the Colony appeared outwardly to be a Christian society, from the Pietistic perspective there was very little depth. For many, Christianity had become a sub-compartment of their life with their real priorities lying elsewhere. This attitude was not only prevalent in Cape Town, but from descriptions by eyewitnesses of church life in Stellenbosch and Zwartland, country parishes were also cause for grave concern (cf. Smit 1945:119-121).

\section{Pietism in Southern Africa}

Reformed Pietism had a solid basis at the Cape of Good Hope through the influence of the 17th century theologians. Perhaps the most influential one was Wilhelmus Brakel, minister in Rotterdam, whose book De Redelijke Godsdienst, found a place in many Dutch households. Amongst others, Abraham Hellenbroeck is usually counted as an exponent of the Second Reformation (Nadere Reformatie). He would exercise a wide influence, mainly through his catechism instruction Voorbeelden der Goddelijke Waarheden which after his death was enlarged as the so called 'Groot of Dubbelde Hellenbroeck' [Hellenbroeck's Larger Catechism] (cf. Brienen 1989:123-145, 181-238; Van Zij1 1993:161-167). It is, however, tempting to rank Hellenbroeck amongst the stream of reformed rationalism that was so widespread during the 18th century. His catechism, which was widely used both in Holland and the colonies, is formal, dogmatic and stresses human reason and the development of correct theories in an almost scholastic fashion. On the other hand, Hellenbroeck's sermons usually gave practical direction and exercises for Christian life, and seemed to support the cause of Reformed Pietism. These early inner tensions may have encouraged the dichotomy between the profession of truth and the heart that would become prevalent in Second Reformation circles at a later date. At any rate, Hellenbroeck preached at Van Lodenstein's funeral and his life shows the close interaction of Pietism with the Age of Reason.

Other Pietist influences came through the songs of the Rev. Jodocus van Lodestein, (Uyt-spanningen) which were very popular, and not only in Holland. Their geographical spread encourages the conclusion that this hymnal was widely used in the homes of the faithful, and in all sociological strata of the Cape Colony (Van Zijl 1993:142-143). Others, like Schortinghuis and Groenewegen followed in the footsteps of Van Lodestein:

Hulle het in reaksie gekom teen die dorre leerheiligheid van die gereformeerde Ortodoksie en die koue beoefening van die Rasionalisme. In lyn met hierdie nadruk op die subjektiewe neig die sanger-eksponente van die Nadere Reformasie, in hulle bogemelde werke, om die bevindelike oor te aksentueer en om in die rigting van versmalde mistiek uit te gaan. [They reacted against the dry doctrinal holiness approach of reformed orthodoxy and 
cold rationalism. In line with this emphasis on the subjective, the hymn writers of the Second Reformation tend to over emphasise experience in these works and seem to be headed for a narrow mysticism.] (Van Zijl 1993:148, [author's own translation])

Toward the end of the 18th century, Pietism saw a revival in Germany, together with the success of the Methodist movement in England. At the Cape it was not always well received by the authorities. Louis van Dijk en Willem Raassel, both of them ziekentroosters (so called comforters of the sick or laymen who were not allowed to preached or serve the Sacraments, but read the set forms of the Church to the sick and dying), were expelled from the Colony in 1743 and 1745 respectively. Their stress on the experience of regeneration encouraged division within the Church. It was this emphasis, combined with the violation of the institutional ordinances at the Cape (particularly the prohibition of sluipvergaderingen [unauthorised religious meetings]), which caused great agitation and led to the untimely departure of the Rev. Harmen H. van der Veen. A sergeant and six soldiers made sure that he actually left the Colony.

The Moravian Brethren also suffered great opposition. The German cultural flavour of their work must have felt unsettling for a still relatively small colony, where all church affairs took place according to the established Dutch Reformed rules in VOC context. The sudden appearance of a minister such as Schmidt, who was, if ordained at all not ordained by the proper organisation, who didn't baptise in a church building, but in a river, who spent most of his time civilising hopeless cases like the Khoi Khoi, stretched their limits too far. The Dutch Reformed ministers from Cape Town, Stellenbosch and Drakenstein, without even conferring with Schmidt, jointly asked for and achieved his removal from the Colony in 1743.

Despite its unpopularity with the powers that be, Reformed Pietism continued to flourish amongst the population. The correspondence between the widow Susanna de Vries and the Rev. Th. Van der Groe in Holland is revealing in this regard. Of this emotional, Pietistic preacher it is said that he could lift people up into the highest heaven and remove them from this elevated state the moment they thought they had found the Lord. 'Hij zal zijn arbeiders wel zenden als de tijd aldaar gekomen is' [God will send his labourers when the time is right] he wrote from the motherland in 1751 (cf. Morrees 1937:238-239). Fourty years later these labourers would arrive in the persons of the ministers Van Lier and Vos.

Van Lier, and subsequently Vos, encouraged an evangelical exposition of Scripture with applications to personal circumstances and needs (Gerdener 1943:153-154). The formal approach to religion in the Cape Colony was challenged by Vos's puritan revivalist preaching and also by the way he encouraged religion in the home as well as evangelism amongst the non-Christian population of South Africa. This was particularly applied to the slaves and Malayan population of the Cape, but should not be restricted to these. Vos wrote a catechism 'ten behoeve van de eigenaars van slaven en andere heidenenen om zoo te leiden tot de kennis der zaligheid' [for the owners of slaves and other gentiles to lead to the knowledge of salvation] (cf. Gerdener 1951b:20). Vos's empathy with the spiritual needs of slaves found a sympathetic ear with, and was perhaps at times mistaken for, the political cause of the anti-slavery movement that sat so well with the new colonial powers.

Vos's Pietistic inclinations and his shared convictions with the Moravian Brethern regarding missions forged a natural bond with them. On his arrival at the Cape after his time of ministry in Holland, Vos called upon the Governor to support the Brethren (cf. Du Plessis 1911a:76-77). The government was delighted with this, as the political inclinations in England at the time followed the same direction. Vos continued to foster this tie and visited the mission station in Baviaanskloof in January 1797, together with other supporters of the mission, amongst whom was the widow Machteld Smith, who had been influenced by Van Lier's preaching. Significantly, the early activities of the South African Missionary Society (SAMS) were all concentrated around Roodezand, where Smith had a home and Vos was the minister. Smith left her occupation in Cape Town and moved to Roodezand where she had a house especially built that was made available to Vos so that he could preach to 150 to 180 'heidensche toehoorders' [pagan hearers] (Vos 1824:117).

\section{Prejudice explained in historic context}

The names of three English contemporaries who exemplify what Vos stood for come to mind: George Whitefield (the necessity of personal faith, experience and conversion), William Carey (a zeal for mission work), and William Wilberforce (an eye for the improvement of the position of slaves). For Vos, however, meeting spiritual needs was his overriding goal. He wasn't a political activist. Vos even supported a law that allowed Christian slaves to be traded. This meant that slaver owners would be prepared to allow Christian teaching and baptism to their slaves considering that they would no longer suffer economic loss as a result of slaves converting. Vos's interest in slaves was always foremost in his mind. This was also because he knew that many White Christians back in Holland and England were far worse off than slaves at the Cape (cf. Vos 1824:14).

Against this historical background, (i.e. the antagonism of the local authorities against both Pietism, his mission work amongst non-Europeans and his support for the slaves) it becomes understandable that the authorities at the Cape were prejudiced against Michiel Vos. To exacerbate matters, when the Dutch government joined forces with the French Revolution one of the men responsible for Vos's appointment happened to take a dislike to the rightwing Prof. Bonnet, who was Vos's friend and teacher in Utrecht. In the light of this powerful opposition it was a small miracle that Vos was ever appointed to a congregation at the Colony in 1793.

Providentially, the British, who were more supportive of Vos's religious and political causes, took over the government in the Cape Colony two years later in order that the French 
revolutionaries could not take possession of the Cape with its important strategic location. However, with the Peace of Amiens in 1803 the colony came back to the Batavian Republic. The governor, Jacob de Mist, did not support the mission causes of Pietism at all. He was only interested in law, order and obedient natives. As far as the Hernhutters (Moravian Brethren) encouraged this, it was fine, but De Mist ruled that any teaching of slaves and natives should take place not closer than a three-day journey from established parishes. To De Mist's credit this served to protect the local church as a regional entity against interference. However it was not a realistic nor practical ruling, as some parish boundaries were so far outstretched that some members travelled ten days to church (cf. Vos 1824:117). De Mist also set the Confession of the Church aside and replaced it with a multi-religious approach, for all practical intents and purposes discarding the established idea of the Dutch nation under God with the Dutch Reformed Church as its spiritual counterpart.

The fact that the established Church or its members avoided Christian responsibilities towards slaves and pagans for economic reasons, practical threats and cultural aversion, whilst others were willing to step in, often from a different cultural and spiritual background (such as the Moravian Brethren), made the situation very complicated. De Mist's opposition against those who stuck to the old ideals of a Christian government and society (inspired by the Belgic Confession) only intensified the problems. As a result of De Mist's measures and the subsequent lack of more public opportunities for the spread of the Gospel amongst those of other nations, the directors of the SAMS started opening their homes for the teaching of slaves following the widow Smith's example.

Vos was greatly discouraged by the fanatical exclusion of slaves from the Sacraments of the Church and the hateful rumours against his person. He consequently left for England in 1802, encouraged by his first wife, who now preferred a European cultural setting without Black people and slaves (Vos 1824:102-104). It is important to emphasise that this was not the hasty retreat that some scholars want us to believe. De Villiers (1959:94) speaks about a 'haastige vertrek na die Ooste' [a hurried departure for the East]. According to De Villiers this was inspired by moral failure. Vos had, however, been cleared of those charges before the magistrate two years earlier, therefore if the rumours about the maid were true, his departure was not all that hurried. Vos also left with praising testimonials from the government and the congregation of Roodezand. The fact that he settled back there with his family after his retirement suggests that there were no skeletons in his closet.

Politically, the year 1802 was an opportune time to leave the Cape, as it was just before the Peace of Amiens came into effect. Vos only returned when the Cape was in English hands once again and the political circumstances were more favourable. Britain was his natural friend, not only because of his contacts with the London Missionary Society, but also as a close ally for his spiritual causes. By 1806 resurgent French power led to another British occupation in order to prevent Napoleon using the Cape. It was three years after this that Vos returned. For the Christian Reformed character of the Colony and its Church it was a blessing that the reign of the Batavian republic did not last (cf. Van der Watt 1989:82). The Cape Colony subsequently remained in the British Empire until the formation of the Union of South Africa in 1910.

\section{Methodist phenomena \\ Emotional agitation}

From the above we see that Vos was a risk for the status quo in the Cape Colony. He represented, from his opponent's perspective, a gloomy and at times emotionally disruptive kind of Christianity. It was a mixture of Calvinism, Methodism and Voetian doctrines (the influential 17th century Dutch Reformed Utrecht professor). Vos's Puritan zeal and Methodist style of preaching evoked fits and emotional displays in his hearers. One of the local sinners in Vos's first parish of Woudenberg complained:

Het is hier in Woudenberg niet meer uit te houden ... Hier ligt er één op zijn knieën schreeuwende over zijn zonden; daar ligt er één, jammerende en schreeuwende om genade: straks worden wij nog allen gek! [One cannot stand the situation in Woudenberg anymore ... Here lies one on his knees crying out loud about his sins; there another, wailing and shouting for mercy: it won't take much more to turn us all utterly mad!] (Vos 1824:73, [author's own translation])

It was not unlike the phenomena that accompanied the preaching of Whitefield and Wesley. It had also touched Presbyterianism in Cambuslang (revivals between the years 1742-1744). In the Netherlands similar effects were observed in other towns where the same kind of preaching prevailed. The Rev. Gerardus Kuypers, for instance, was instrumental in what would become known as the Nijkerkse Beroeringen, that is, the upheavals in the small town of Nijkerk in Gelderland (1749) which led to long-lasting spiritual renewal locally (cf. Van der Meiden 1993:118-119).

\section{Pietist subculture}

The government-centred church in the Cape Colony was not waiting for this kind of Methodist upheaval. They would do anything for a quiet life and clear boundaries of authority. Many colonials enjoyed the 'good life' as well, and were not particularly eager for a Pietistic brand of puritanism to take over. Other cultural aspects of Pietism, such as its terminology, were misunderstood and rejected with disgust. Heinrich Liechtenstein ('Travels in Southern Africa in the Years 1803, 1804, 1805 and 1806') $)^{2}$ loathed the 'tjankerige gemaakte nederigheid' [the fake wailing show of humility] that he seemed to regard part of Vos's character (Du Plessis 1911b:230; Morrees 1937:347). However, Liechtenstein visited the Cape a year after Vos had already left for England and during the anti-Pietistic government of the Batavian Republic. Liechtenstein shows bias in other respects, rejecting the mission endeavours in South Africa as bigotry and seeing puritanism as an unforgivable disruptor.

2.M.K.H. Lichtenstein, (1813, 1814). Reizen in het zuidelyk gedeelte van Afrika in de jaren 1803, 1804, 1805 en 1806, deel 1-3, vertaald vanuit het Duits door W. Goede, A. Blusse \& Zoon, Dordrecht. 
Despite this, it is worthwhile to explore Liechtenstein's accusation or hearsay about humility as a performance that reformed Pietistic ministers were supposed to sustain. Some expressions in Vos's autobiography seem to encourage judgement of his character. For example, we read that he speaks of 'my humble labours', but discover in the same sentence that these 'are blessed' and 'clearly blessed' in the next sentence (Vos 1824:51). But if one takes the context into account, Vos expresses himself very naturally without any self-glorification. Infact, the contrary is the case. It was a difficult time and he was glad that some good could arise from it, despite the church politics that he was subjected to and the pain arising from this.

Met hoe veel moeite ondertusschen, en onder hoe vele aanvallen van den vorst der duisternisse, ik mijnen geringen arbeid in dien groote stad verrigtte, zoo liet mijn groote Zender denzelven evenwel niet ongezegend. [Although I worked my humble labours in this great city under many trials in the meanwhile, and suffered under many attacks of the prince of darkness, even so my great Sender did not leave these without blessing.] (Vos 1824:51, [author's own translation])

The same is true when he refers to himself as 'God's unworthy servant' (Vos 1824:115). This is in the context of God blessing his little catechism book for the instruction of slaves by their masters despite fierce opposition. This attitude is also evident when he reflects on the entire history of his life (Vos 1824:212-213). Generally, his autobiography gives a genuine and balanced impression.

In hindsight one could say that what may have been genuine spiritual expressions within the subculture of Reformed Pietism were not always experienced that way by outsiders. Especially when considering that the still prevailing tendency in those circles was to change one's tone of voice if spiritual matters were discussed, sinking to an almost wailing lament when it came to man's natural ability to do something useful (cf. Klei 1992:74-79). Whether this should reflect on Vos's character, either as a flaw or a genuine appreciation of the grace of God, is very hard to say in the light of the available information two centuries later.

\section{Vos's mission endeavours in context The first African mission society}

Together with the person of William Carey (who published his An Enquiry into the Obligations of Christians to use means for the Conversion of the Heathens in 1792 (cf. Beusekom 1935:35-36), Vos was part of an age that had awakened to the importance of missions. Already as a young convert, Vos felt a need for missions and had a heart to spread the Gospel amongst the slaves and Hottentots. It was this unpopular venture, together with Vos's alliance with Reformed Pietism, that caused the authorities not to encourage him on the path of the ministry. They firstly prevented him from going to seminary and when he had overcome this obstacle, they obstructed his return to the Cape for another ten years after his studies. Missionaries were often unpopular with settlers. During this pioneering age, missionaries sometimes proved insensitive to economic necessities, such as the survival of farmers and small businesses. It was relatively easy for them to cultivate ideas that local settlers had to pay for or to ignore cultural differences and overlook misbehaviour as part of their crusade.

According to Du Plessis (1911a:79), 'Vos was one of the first and one of the best missionaries South Africa has ever had'. For Vos charity began at home. He did not neglect the spiritual condition of his own slaves, two of whom were converted (cf. Du Plessis 1911a:422). In Vos the causes of Pietism and mission work were combined, much in the way it had been with Van Lier, who had been sympathetic to the Moravians as well (Hanekom 1959:321; cf. Crafford 1982:23; Du Plessis 1911b:239-240; Van Heerden 1951:42-43). It must be mentioned in this context that Vos was supported in his sympathy of the Moravians by several directors of the East India Company and members of the Classis (Presbytery) of Amsterdam, under which the Church at the Cape resorted. This was by no means a new attitude. The Classis Amsterdam severely reprimanded the Dutch Reformed ministers in the Colony about the way they had conspired with the civil authorities to remove the Moravian missionary Schmidt.

In his work Vos was strongly motivated by the Bible. It was holy Writ and the Spirit that had touched his life and called him to the ministry of Jesus. He started his activities in Roodezand with an induction sermon on the words of Mark 16:15: 'Gaat henen in de geheele wereld, predikt het Evangelie allen creaturen' [Go into all the world and preach the Gospel to all creatures] (Vos 1824:115). Vos told his new congregation that, as far as he was concerned, 'all creatures' included slaves and natives. He asked for the co-operation of any in the congregation who had slaves or free natives working for them by sending them to Vos for instruction in the Christian religion every Wednesday and Sunday. This spiritual responsibility was clearly not felt before, '[d]eze mijne aankondiging en uitnoodiging verwekte geene kleine ontsteltenis in mijne gemeente' [My announcement and invitation was cause for no small disturbance in my congregation] (Vos 1824:11).

Nonetheless Vos persevered. When the South African Society for the Advancement of the Kingdom of Christ was established, it was at Vos's home that they decided to use lots to decide which of the missionaries should go to the Bushmen and which to the Xhosas (without prejudice referred to as Kaffers by Vos and in 19th century literature):

Voorts kwamen deze zendelingen, onder mijn geleide naar het Rodezand, alwaar de Engelsche broeders, die niet geordend waren, en echter, wanneer God hunnen arbeid onder de Heidenenen zegende, geordend moesten zijn, als zij de Sacramenten aan hen bedienen wilden, door Doctor van der Kemp, (die daartoe van het Europeesch Genootschap geautoriseerd was) in mijne kerk, geordend werden. Deze eerste ordening, welke ooit in ZuidAfrika heeft plaats gehad, werd door vele nabij wonenden uit mijne gemeente met groote aandoening, bijgewoond. Ook werd toen bij mij aan huis door het lot beslist, dat de Heer Kicherer met den Heer Edwards naar de Boschjesmannen gaan zouden; terwijl van der Kemp en Edmond zich naar Kafferland begeven moesten. [Further, I accompanied these missionaries to the Rodezand, 
where these English brothers, who were not ordained, were ordained in my church by Dr Van der Kemp (who was authorised to do so by the European Society), as they, when God blessed their labours amongst the Pagans, should be ordained to be able to administer the Sacraments to them. This first ordination, the first one ever in South Africa, was attended by many from my congregation who lived close by, who were really touched. Also on that occasion it was decided in my home by means of lots, that Mr Kicherer and Mr Edwards should go to the Bushmen; whilst Van der Kemp and Edmond should go to Kaffirland.] (Vos 1824: 21, [author's own translation])

The societal approach to missions brought tension within the established church. The new missionaries were not ordained by the local Church, or any church for that matter, but on the authority of a European mission society far away. How could an organisation that was not a church decide to ordain and send out ministers? Why should a society that was distant, not only in kilometres but also in culture and with a bias for English empire building, rule it over the local affairs of an established colony of the Dutch Republic? It was a pragmatic solution that Pietism should embrace the Mission societies. The official church was no longer run by people that were likeminded in their zeal for the Gospel, as it had been in the days of Voetius, Brakel (1893) and Van Riebeeck. In the Scriptures, which were so highly regarded by the reformed Pietists, mission was a responsibility and activity of the ordained ministry of the Church of Christ (cf. Mt 28), as was the command to baptise new believers. If this was something the Church was not prepared to do, the prevailing thought amongst Vos and his contemporaries was that some kind of action needed to take place although he felt much more restraint with regard to this than the others (Vos 1824:121).

\section{Racial struggles and Christian unity}

In the Cape Colony, the sale of baptised Christians into slavery or into other hands was forbidden by law. As slavery was a form of social security for the disadvantaged, on setting a slave free the owner had to donate a substantial sum of money to the church, in case the slave would come to rely on support from the deacons. Rather than encouraging Christians to make economic sacrifice or to seek creative and alternative strategies, Vos opted to disapprove of the law. He gave this law as his reason for not baptising slaves who converted to Christianity:

En o! welk eene smerte voor mij! dat ik, volgens eene hier bestaande Landswet, (welke ik nooit heb kunnen goedkeuren) deze schepselen, die God door zijne genade tot Christenen gemaakt had, niet door den Heiligen Doop ook uitwendig tot Christenen maken mogt; die wet verbood zulks wel niet onmiddellijk, maar bepaalde, dat de gedoopte slaven niet mochten verkocht worden. [And, o, what a grief it was to me, that according to one of the laws of the country, which I never approved of, that I was not allowed to confirm outwardly by Holy Baptism as Christians, those creatures, who God in his grace turned into Christians inwardly. This law did not prohibit this as such, but ordained that baptised slaves should not be sold.] (Vos 1824: 127-128, [author's own translation])

This old Dutch law, however, which was later repelled by the English, at least treated any Christian equally with no regard to colour or race. It allowed no second-rate Christianity, that is, one for White people, a separate one for people of mixed race and one for the slave population. By supporting the inferior strategy of compromising with economic values, obeying powerful merchants rather than God's command to baptise believers, when the law was repelled and baptism took place only on secular terms, Vos and the Mission Society encouraged the development of apartheid in the State and Church denying Christianity its former role as the unifying factor for all races.

The primacy of Christianity as a consideration for one's civil status was at least as old as the Middle Ages and was recognised in the early days of Van Riebeeck and the French Huguenots. The Hottentot girl, Eva, received a Dutch education in the Van Riebeeck household and became a Christian (Boëseken 1966:27, 45). Because she was baptised by the Rev. Petrus Sibilius in 1662, she was even buried in church. Although some Vrijburgers [free settlers] disapproved of the mixed marriage, her colour did not make any difference to unified Christian culture at the Cape, nor did her moral waywardness after her Danish husband's death, which may have been caused by her lack of opportunity to remarry suitably. Whilst she neglected her children, the Deacons took care of them, despite their colour and completely non-Dutch background on both the father's and the mother's side. Long lists of converted slaves and Hottentots would follow in the colonial registers. Although there is no evidence of any wider mission enterprise amongst the natives, this demonstrates that Christianity was a unifying factor for which people were prepared to make allowance and even sacrifice for beyond the borders of colour and race.

How different the situation would be only a century later, when the world would become touched by the civil ideals of the French Revolution. As God and Kings disappeared, nationhood and bloodlines became political tools to serve the economic goals of empire building. Although the commercial interests of the VOC sometimes challenged this, under the old system, Church and State were subdepartments of the same kingdom, each with their own sphere of responsibilities. The State was supposed to support and protect the Church, even to fight false religion, according to Article 36 of the Belgic Confession. During the 18th and 19th centuries, with the advancement of secular rationalism and the ideals of the French Revolution, Christianity was replaced by Humanism as a unifying factor for State life. The Age of Race and Nationhood was about to begin. Vos operated in the early stages of this development.

\section{Central idea: The man and his mission}

There is only one leading thought in the autobiography of the Rev. M.C. Vos, which is cherished and advertised by its author time and again: God calls, guides and provides. For Vos this even happens despite situations of human inability, want and severe testing.

This is particularly evident in the first, original edition of the autobiography, which carries, after the title page, the words, 'EBEN HAËZER. Tot hiertoe heeft de Heere geholpen (I Samuel VII, 12b).' [Ebenezer. Thus far has the Lord helped. (1 Samuel 7:12b)] (Vos 1824:vi). 
In later editions this tribute is left out, but the book itself continues to supply ample evidence for this leading thought:

Hoe lang zelfs na uw overlijden, en hoe verre in de wereld kunt gij niet arbeiden en onder den Goddelijken zegen nut doen aan de belangen van onsterfelijke zielen door uwe geschriften! [For how long even after your passing away, and how far in the world you will be able to labour under the Divine blessing, doing well to the interests of unperishable souls through your writings!] (Vos 1824: $\mathrm{x}$, [authors own translation])

Michiel Vos had to overcome many a trial and tribulation. For one thing, there probably wasn't a day in his life that he was completely healthy. For example, he nearly died whilest ministering in his first congregation in Holland, just before the arrival of his first wife (Vos 1824:60). He suffered from a common skin disease (Vos 1824:1-2), which was probably 'dauwworm' (lit. 'dew-worm', a serious form of eczema, affecting infants). It can take the form of a circular wet infection of the skin, which is not contagious, but predisposes the sufferer to bronchitis, asthma and hay fever. This was consistent with the chest complaints and spasms in the lungs that Vos experienced in adulthood (Vos 1824:59-60). When he was only five years old his father passed away, but Vos recalled and recounted his tender care many years later (Vos 1824:2). His mother subsequently remarried, but continued to pay every attention to Michiel's health and survival. Her treatments proved successful and he was able to take on an apprenticeship as a silver and goldsmith with his brother when he was about 14 years old. At night after work, he learned to draw and to play the piano, as he loved music (Vos 1824:5-6).

As a young man he felt the heavy burden of the Lord and perceived His calling to proclaim the Gospel amongst slaves and pagans. He had to overcome continued opposition by the Head of the Orphanage Chamber to have his inheritance released so that he would be able to prepare himself for the ministry at one of the academies in Holland, as the Cape did not have a seminary at the time. Through the support of his in-laws, he left his widowed mother and his new wife behind as part of an arrangement to overcome the opposition of the authorities. And he finally succeeded, only to receive a solemn warning from his doctor that he was certain to die during the passage if he travelled to Holland for his theological studies (Vos 1824:26-27). This was indeed a journey of faith!

After four years away from his beloved wife and family, church politics kept him from returning to the Cape (cf. Van Rinsum 2006:29). Consequently Vos spent 14 years in exile, but they were not fruitless years. During this time he gained experience and stature as a minister, which would prepare him to take the right course of action despite opposition. He displayed a fine sense of humour, when he pointed to God's providence in arranging things in such a way that even the opposition was used for his purposes. God didn't always make sense, but he made enough sense to Vos for him to continue to trust him and to work for him. One of those events was Vos's forced stay in Holland, involuntary relocation of his first wife against all expectations and his mother's passing away during his absence from the Cape Colony. Despite the questions, Vos's recurring thought was: 'Gods weg en leiding met mij, van mijne geboorte af tot hiertoe.' [God's way and guidance for me, from my birth until now] (Vos 1824:212).

God cares and guides. In this Vos tried to serve God's purpose in his generation. He saw himself as a tool in the hand of God and tried to be sensitive to divine guidance rather than his own plans. M.C. Vos's missionary endeavours should be understood in this light. The love of Christ led to a love of souls and at the Cape situation he saw that it was the souls of slaves that were much neglected. This filled him with compassion. His life was changed by the Word of God and Bible verses interacted with his life (Vos 1824:13-14). From this perspective, he was amazed that none of the preachers or even any of the Christians he admired, apparently noticed this particular need to proclaim the Gospel amongst the slaves. To Vos, this was a biblical issue, not a racial or even a slavery issue. He showed himself a careful exegete, who carefully counteracted quotations from Scripture that Europeans used at the time to justify their spiritual neglect of slaves and natives. Vos's compassion for slaves and natives was not a political issue, but a spiritual one. Unlike others, he wasn't willing to work with cheap accusations and caricatures of the opposition. On the contrary:

... niet zozeer over hunne slavernij, (want velen hunner hebben het, naar den lichame, inderdaad veel beter dan duizenden vrije Christenen in Europa; worden niet mishandeld, hebben het onbezorgde voedsel en deksel, worden in ziekte van alles kosteloos voorzien, en behoeven, indien zij gehuwd zijn, voor niets, noch voor zich, noch voor hun kroost te zorgen) maar mijn hartzeer was over de verwaarloozing hunner onsterfelijke zielen. [... not about their slavery, because many of them are, as far as the body is concerned, really much better off than thousands of free Christians in Europe; they are not abused, have carefree food and raiment, receive everything they need in time of illness without cost, and if they are married, they don't have to support themselves or their families, but my compassionate pain was about the neglect of their immortal souls.] (Vos 1824:14, [author's own translation])

This is what distinguishes Vos from several of his activist contemporaries, like Van der Kemp. Vos writes (1824:133), 'maar kon het met den grooten Van der Kemp in sommige opzigten niet eens worden'. [But in some respects I was never able to agree with the great Van der Kemp.] Although both are regarded as evangelical Christians, Van der Kemp had a very different background and agenda. After a life as a soldier and serial adulterer, he became an evangelical Christian and married a 13 year old girl, 40 years his junior, whose father was a Muslim. Unlike Vos's Reformed Pietism, Van der Kemp's philosophy was rooted in Spinoza and Descartes. He did not think much of European settlers and attacked them publicly on many occasions, but many of his accusations turned out to be ill-founded rumours (Elbourne 2002:94-110). After his death, even his relatives and friends criticised him 
'for allowing his religious enthusiasm to undermine common sense and propriety and lead him to identify too closely with the Khoi-Khoi or, more generically, with the natives' (Cox 2008:108).

Vos had a more balanced approached. Although the opposition remained opposition, he had no need to demonise it with political strategies of his own. On the contrary, he loathed those who misrepresented the colonial farmers in their travelling journals. Vos (1824) said:

Daar ik niet slechts ééns, maar eenige jaren later, op verzoek van het Gourvernement, nogmaals zulk eene reis, tot aan de grenzen van Kafferland, gedaan heb, zal ik nooit bevestigen de lasteringen, welke de meeste reisbeschrijvers door Afrika velen der Afrikaansche boeren aangedaan hebben; hetgeen zoo veel te slechter is, dewijl zij van diezelfde personen en huisgezinnen, op hunne reizen, menigmaal geholpen en welgedaan werden: zoodat zij, zonder de hulp en den bijstand van hen, en dat meestal zonder de minste belooning te begeeren, hunne reize onmogelijk zouden hebben kunnen volbrengen. Ook hebben die reisbeschrijvers, door hunne anderzins nuttige boeken zoo zeer te bekladden, veel kwaad voor volgende reizigers uitgewerkt. [Because I made not just, but a few years later, another journey to the borders of Kaffirland, at the request of the government, I will firmly deny the slander that most writers who travelled through Africa committed against the Dutch farmers who settled there. This is so much worse, as many times they received aid and assistance from these same people and their families, without which their travels would have been impossible. By polluting their otherwise useful books, these authors of travelling journals have caused much harm to subsequent travellers.] (p. 125, [author's own translation])

M.C. Vos was not a political activist who only saw one aspect of the situation. He was a pastor.

\section{Conclusion}

The real motivating factor for Vos's missionary endeavours was not racial, but spiritual. The promotion of the Gospel and knowledge of the Scriptures was foremost in the mind of this Dutch Reformed minister. The Bible and divine guidance had a remarkable influence on the life and actions of M.C. Vos, and enabled him to overcome significant opposition and challenging situations. His mission was a spiritual one. His main concern was the souls of men, Black people and White people alike, as he ministered amongst all races at the Cape of Good Hope and far beyond. Vos also marks the beginning of international and supradenominational co-operation in missions through his involvement in the London Missionary Society and contacts with the Moravian Brethren. Future research should bring to light which influences in Church and State contributed to this and to what extent the Dutch Reformed Church in South Africa followed in Vos's footsteps.

Vos's clinging to Divine revelation for guidance and motivation for his life, is what makes his autobiography a truly remarkable story, inspired by the Holy Scriptures and a genuine tribute to the providence of God.

\section{Acknowledgements Competing interests}

The author declares that he has no financial or personal relationship which may have inappropriately influenced him in writing this article.

\section{References}

Algra, A. \& Algra, H., 1972, Dispereert niet, twintig eeuwen histgorie van de Nederlanden, deel 4, T. Wever, Franeker.

Beusekom, H.G., 1935, William Carey, de Grondlegger der hedendaagsche Zending, Den Haag, Voorhoeve.

Boëseken, A.J., 1966, Die Nuusbode, Nasionale Opvoedkundige Uitgewery, Kaapstad.

Brakel, W., 1893, De redelijke Godsdienst, In welke de Goddelijke waarheden van het genadeverbond worden verklaard, tegenpartijen beschermd en tot beoefening aangedrongen, alsmede de bedeling des verbonds in het Oude en Nieuwe Testament en de ontmoeting der kerk in het Nieuwe Testament, vertoond in een verklaring van de Openbaring van Johannes, Onveranderd uitgegeven naar de beste uitgaven, D. Donner, Leiden.

Brienen, T., 1986, De Nadere Reformatie, Beschrijving van Vertegenwoordigers, Boekencentrum, Gravenhage.

Brienen, T., 1989, De Nadere Reformatie en het Gereformeerd Pietisme, Boekencentrum, Gravenhage.

Conradie, B., 1951, Andrew Murray na honderd jaar, Die Christenstudenteverenigings maatskappy, Stellenbosch.

Cox, J., 2008, The British missionary enterprise since 1700, Routledge, New York.

Crafford, D., 1982, Aan God die Dank, Deel I, N.G. Kerkuitgewers, Pretoria.

De Villiers, D.W., 1959, Reisbeskrywings as Bronne vir die Kerkgeskiedskrywing van die N.G. Kerk in Suid-Afrika tot 1853, Kok, Kampen.

Du Plessis, J., 1911a, A History of Christian Missions in South Africa, Longman \& Green, London.

Du Plessis, J., 1911b, Merkwaardig Verhaal aangaande het Leven en de Lotgevallen van M.C. Vos, Hollands-Afrikaanse Uitgeversmaatschappij, Kaapstad.

Elbourne, E., 2002, Blood ground: Colonialism, missions, and the contest for Christianity in the Cape Colony and Britain, 1799-1853, McGill-Queen's Press, Montreal.

Elphick, R., 1997, Christianity in South Africa: a Political, social, and cultural history, University of California Press, Berkely.

Gerdener, G.B.A., 1943, Die Boodskap van 'n Man, Lewenskets van Prof. J. du Plessis, Christen-Studentevereniging van Suid-Afrika, Stellenbosch.

Gerdener, G.B.A., 1951a, Bouwers van weleer, NG Kerkuitgewers, Kaapstad.

Gerdener, G.B.A., 1951b, Reguit koers gehou: Die wording, wese en werking van die N.G. Kerk se sendingbeleid, NG Kerkuitgewers, Kaapstad.

Hanekom, T.N., 1959, Helperus ritzema Van Lier: Die lewensbeeld van 'n Kaapse predikant uit die 18de Eeu, N.G. Kerkuitgewers, Kaapstad.

Huigen, S., 1997, 'Michiel Christiaan Vos, de eerste zwarte schrijver in Zuid-Afrika' [Michiel Christiaan Vos, the first Black writer in South Africa], Tydskrif vir Nederlands en Afrikaans, 4(2), 203-209.

Klei, A.J., 1992, De koningin is lekker hervormd! Over Kerken en kerkmensen in Nederland, Ten Have, Baarn.

Marks, S., 1972, 'Shula Marks (1972), Khoisan resistance to the Dutch in the seventeenth and eighteenth centuries', The Journal of African History (13), 55-80.

Morrees, A., 1937, Die Nederduitse Gereformeerde Kerk in Suid-Afrika 1652-1873, S.A., Bijbelvereniging, Kaapstad.

Rosseau, L., 2002, 'Vroeë 'swart' skrywer lyk Europees', Die Burger, 27 Maart.

Smit, A.P., 1945, Gedenkboek van die N.G. Gemeente Swartland, tweede Eeufees (1745-1945), N.G. Kerkraad, Malmesbury.

Van Der Meiden, A., 1993, De zwarte kousen kerken, bevindelijk heroverwogen portret, Ten Have, Baarn.

Van Der Watt, P.B., 1989, Die Nederduits Gereformeerde Kerk 1652-1905, N.G. Kerkboekhandel, Pretoria.

Van Heerden, G.L., 1951, Twee eeue van sendingwerk: 'n Oorsig oor ons Kerk se sendingwerk in Suid-Afrika 1652-1857, N.G. Kerkuitgewers, Kaapstad.

Van Rinsum, H.J., 2006, Sol lustitiae en De Kaap: Een geschiedenis van de banden van de Utrechtse Universiteit met Zuid-Afrika, Verloren, Hilversum.

Van Zijl, W., 1993, Van skeepskis na wakis tot boekrak, Lux Verbi, Kaapstad.

Vos, M.C., 1824, Merkwaardig verhaal aangaande het leven en de lotgevallen van Michiel Christiaan Vos als predikant der hervormde christelijke gemeente op onderscheidene plaatsen in Nederland, Afrika en Azië, van zijne jeugd af tot den tijd van zijn Emeritusschap door hem zelven in den jare 1819 briefsgewijze aan eenen vriend medegedeeld, A.B. Saakes, Amsterdam. 